\title{
SOME FISSIDENS SPECIES NEW FOR BELGIUM AND THE NETHERLANDS*
}

\author{
M. A. BRUGGEMAN-NANNENGA
}

Instituut voor Systematische Plantkunde, Utrecht

\section{SUMMARY}

Two not previously recorded Belgian indigenes, viz. $F$. arnoldii Ruth. and $F$. monguillonii Thér., and one new Dutch one are reported. It is pointed out how these species can be distinguished from those species with which they are most likely to be confused. It is also indicated in what kind of habitat they are to be expected.

\section{F. rufulus B.S.G. new for the Netherlands (figs. 1, 4,5 and 6)}

Between the years 1843 and 1893 this species was collected quite often in the Netherlands. It was found at several places near Dordrecht by Van de Sande Lacoste, while Top collected it near Kampen and Zwolle**. These specimens were not recognized as belonging to $F$. rufulus but were referred to $F$. crassipes Wils. ex B.S.G. There are no new Dutch finds of $F$. rufulus since 1893.

When trying to identify $F$. rufulus with the "Mossentabel" by Margadant (1959) we arrive at $F$. crassipes. Indeed, both species are quite similar in several respects. They both have a conspicuous border, antheridia that are produced terminally, either on normal plants or on small axillary ones, and a borderless apex. Besides, both species are found on stones in or near running water.

$F$. rufulus can be distinguished from $F$. crassipes by its smaller cells. The cells in the middle part of the dorsal lamina of the leaves of $F$. rufulus are 4-8 um long (fig. 6), while those of $F$. crassipes are (7) 11-22 $\mu \mathrm{m}$ long (fig. 7). Another difference is to be found in the shape of the leaves from the middle part of the stem of plants without archegonia, antheridia, or sporangia. Usually, in $F$. rufulus the width of these leaves is the same for a large part of their length (figs. 1 and 4 ), whereas in $F$. crassipes the greatest width lies in the middle of the leaf; from there the leaf tapers to base and apex (figs. 2 and 3).

$F$. rufulus is to be expected in the same places as $F$. crassipes, namely on stones or, rarely, on other firm objects such as wood in or near running water. It is a rather common species in a large part of Europe.

\section{F. monguillonii Thér. new for Belgium ( figs. 8,9 and 11)}

This record too concerns an old collection. The first and up till now the only time $F$. monguillonii was collected in Belgium was when Vandenbroek found it

- Mededelingen van het Botanisch Museum en Herbarium van de Rijksuniversiteit te Utrecht No. 407.

** All these samples are present in the Leiden Herbarium, except for one of those collected by Top which is in the collection of Brotherus in the Herbarium at Helsinki. 


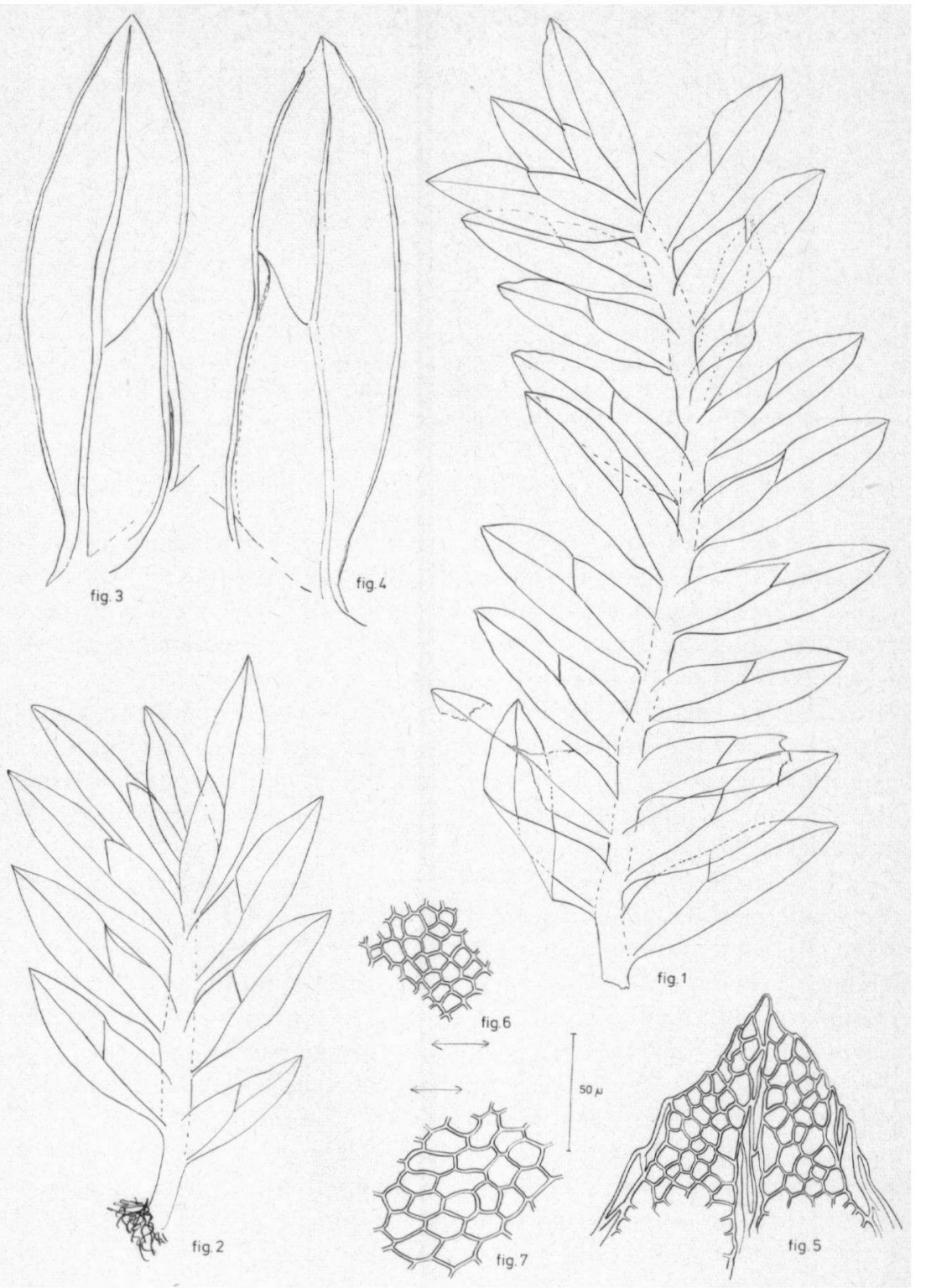

Fig. 1, 4, 5 and 6: $F$. rufulus B. S. G. from Van de Sande Lacoste, Dordrecht 1844. Fig. 1 : part of a plant (lenght of the pictured part $6.2 \mathrm{~mm}$ ); Fig. 4: leaf (length $1.6 \mathrm{~mm}$ ); Fig. 5: leaf apex; Fig. 6: cells. - Fig. 2, 3 and 7: F. crassipes Wils. ex B.S.G. from Bruggeman 386. Fig. 2: plant (length $4.5 \mathrm{~mm}$ ); Fig. 3: leaf (length $1.6 \mathrm{~mm}$ ); Fig. 7: cells. - The arrows in fig. 6 and 7 show the orientation of the leaf axis. The enlargement given between the figures applies to the figures 5,6 and 7 . 


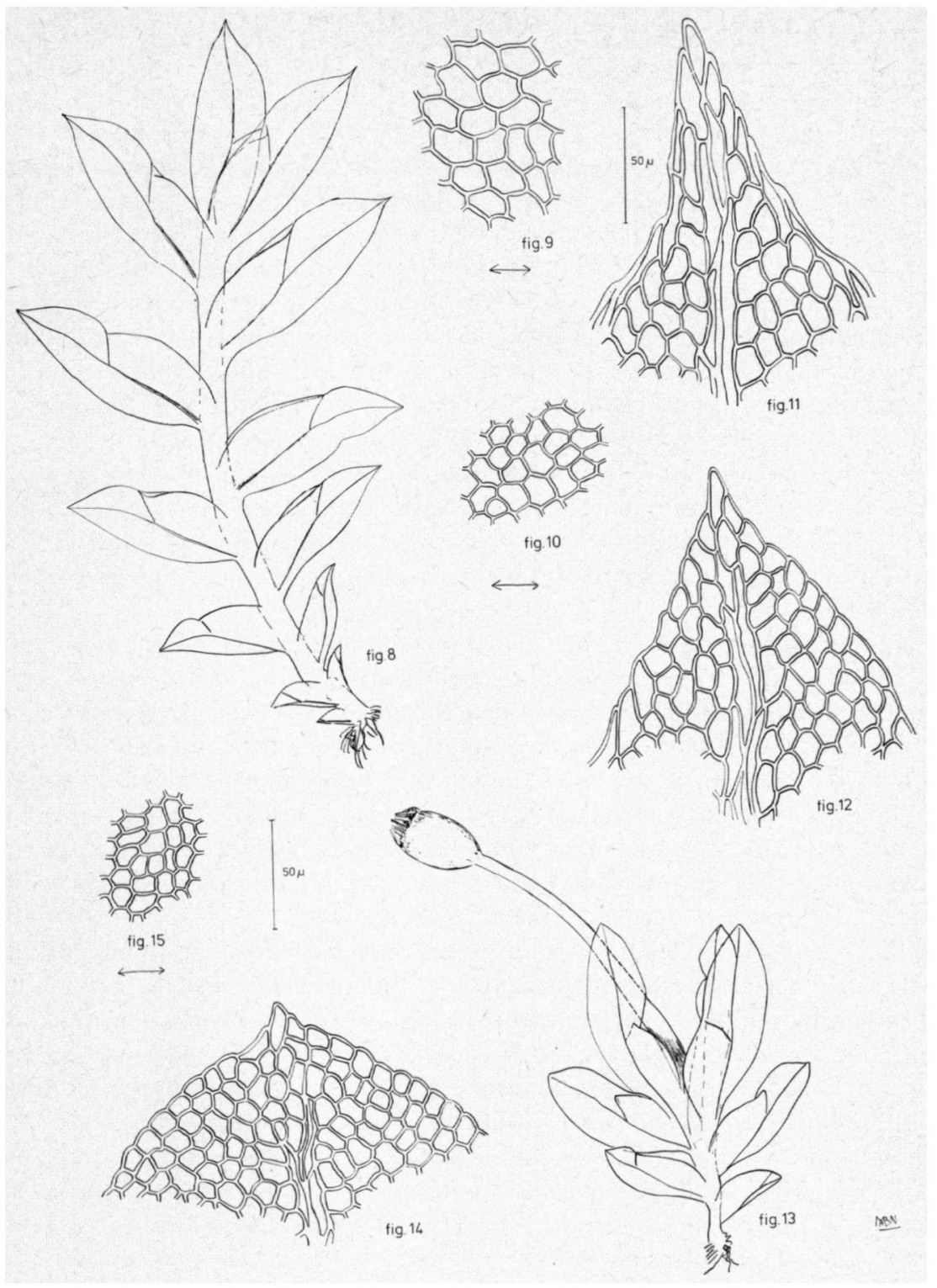

Fig. 8, 9 and 11: $F$. monguillonii Thêr. from Vandenbroek, Edeghem. Fig. 8: plant (length $5 \mathrm{~mm}$ ); Fig. 9: cells; Fig. 11 : leaf apex. - Fig. 12: leaf apex of $F$. crassipes Wils. ex B.S.G. from Bruggeman 386. - Fig. 13, 14 and 15: $F$. arnoldii Ruth. from Bruggeman 424. Fig. 13: plant (length without sporophyte $2.2 \mathrm{~mm}$ ); Fig. 14: leaf apex; Fig. 15 cells. - The arrows in fig. 9, 10 and 15 show the orientation of the leaf axis. The enlargement given between the figures applies to fig. $9,10,11,12,14$ and 15 . 
at Edeghem in 1904. This sample is present in the herbaria of Brussels and Helsinki.

$F$. monguillonii has occasionally been confused with $F$. crassipes. In fact, the present sample was cited as $F$. crassipes by Demaret and Castagne (1959) in their "Flore générale de Belgique, Bryophytes II". These two species resemble each other in the large size of their cells, but in all other respects they are quite distinct. They can easily be separated by the shape of the leaf apex, by the position of the antheridia, and by their ecology. Though in nearly all samples of $F$. monguillonii a few small leaves can be found with a delicate, narrowly acute, apex, the apex as a rule is an acumen or an acuminate mucro (fig. 11). The apex of $F$. crassipes is acute ( fig. 12), but never as delicately and as narrowly as that of small leaves of $F$. monguillonii. Another difference is that in $F$. crassipes the antheridia are always produced terminally, whereas $F$. monguillonii usually has terminal antheridia as well as antheridia in axillary buds. Both species also differ by their ecology, for though both are found in or near running water, they grow on different substrates. $F$. crassipes grows on stones, while $F$. monguillonii is never found on rocks, at least not on naked ones, but develops on soil.

When we try to identify $F$. monguillonii with the Belgian moss flora of Demaret and Castagne (1959) we arrive at $F$. bryoides Hedw., to which species it is indeed much more closely related than it is to $F$. crassipes. Demaret and Castagne discern two varieties of $F$. bryoides, viz. var. bryoides and var. caespitans Schimp. For reasons that I will expound in a future paper these two varieties should be considered to be of subspecific rank; var. caespitans, moreover, should be called subsp. curnovii (Mitt.) Dix. Both these subspecies have, like $F$. monguillonii, axillary antheridial buds and rather broad leaves with an acuminate or acuminately mucronate apex.

$F$. monguillonii differs from both subspecies by having not only axillary antheridia, but also terminal ones, and by the much larger cells. The cells in the middle part of the dorsal lamina of the leaves of $F$. monguillonii are 7-22 $\mu \mathrm{m}$ long ( fig. 9), while those of the two subspecies of $F$. bryoides are (6) 7-11 (15) $\mu \mathrm{m}$ long (fig. 10). From subspecies bryoides it differs, moreover, by its ecology. While $F$. monguillonii is found in or near running water, $F$. bryoides subsp. bryoides normally grows in less wet places. The colour of the rhizoids may serve to separate $F$. monguillonii from $F$. bryoides subsp. curnovii. The rhizoids of $F$. monguillonii are brown, those of $F$. bryoides subsp. curnovii red.

My own - not Belgian, but French - collections of $F$. monguillonii are from densely shaded places. So far $F$. monguillonii is known from England, Ireland, France, Spain, and several islands along the West coast of Africa. It"will probably prove to be a less.rare species than it is generally assumed to be.

\section{F. arnoldii Ruth. new for Belgium (figs. 13,14 and 15)}

This small species was collected by me on rocks in the river Semois near Frahan. This sample is in my own collection. 
Unlike $F$. monguillonii and $F$. rufulus the present species does not belong to the section of Fissidens that I am revising, viz. Pachylomidium, nor do the two species with which it might be confused. This means that for comparision of $F$. arnoldii with these species I will have to rely on information provided by the literature.

When trying to identify $F$. arnoldii with the key of Demaret and Castagne we arrive either at $F$. bambergeri Schimp. in Mild. or at $F$. exilis Hedw. It differs from these species by its ecology. $F$. bambergeri and $F$. exilis are terrestial species that grow on soil, while $F$. arnoldii grows on stones and is submerged during part of the year. Besides, $F$. arnoldii differs from $F$. bambergeri by the border of its leaves. In $F$. bambergeri the border may be restrained to the sheathing lamina, though it is mostly also present in the middle part of the dorsal and the lowermost part of the apical lamina. In $F$. arnoldii the border is either entirely absent or confined to the sheathing lamina of the uppermost leaves. From $F$. exilis it differs by the margin of its leaves, which is crenulate in $F$. exilis and entire in $F$. arnoldii. I expect that the dissimilarity in ecology will prove to be the most reliable one of these three differences.

$F$. arnoldii is to be expected on stones in running water. It often grows mixed with other Fissidens species such as $F$. rufulus, $F$. crassipes, and $F$. minutulus. It has been reported from Germany, France, Holland, Switserland, Czechoslovakia, and Hungary.

\section{ACKNOWLEDGEMENTS}

I wish to express my gratitude to Dr. P. A. Florschütz and Prof. Dr. C. E. B. Bremekamp for their valuable suggestions and to the latter also for his correction of the English text. 